\title{
建築物の地震後機能回復性の観点からの損傷評価指標 \\ DAMAGE EVALUATION INDEX FROM THE VIEWPOINT OF POST-SEISMIC FUNCTIONAL RECOVERY
}

\author{
衣笠秀行*1, 向井智久*2 \\ Hideyuki KINUGASA and Tomohisa MUKAI
}

\begin{abstract}
An index, "Ideal Repair Time (IRT)", to evaluate the severity of earthquake damage from the viewpoint of post-seismic functional recovery was proposed, in which severity is defined to be caused by an increase in repair time. The index was formulated taking into consideration the effects of damage state (i.e. amount, extent, and quality of the damage) on an increase in repair time. The IRTreasonably evaluates the relative increase in repair time generated by the damage state. The analysis using the $I R T$ allows structural designers to investigate the validity of the planned collapse mechanism from the perspective of functional recovery.
\end{abstract}

Keywords : Damage evaluation index, Ideal repair time, Reparability, Post-seismic functional recovery, Damage-resistant performance 損傷評価指標，理想修復時間，修復性，地震後機能回復性，而損傷性能

\section{1. はじめに}

最近の地震被害において、構造体の損傷は小さく安全性に問題は なくても、非構造部材を含めた建物の損傷が大きいために、経済活 動や人々の生活に支障が生じるケースが報告され例えば 1)、耐震設計 における建物の地震後機能継続性に関寸る検討の必要性が強く認識 されるようになった。

一方、特に高層建物において、全体崩壊形を計画し、損傷を建物 全体に分散させ地震エネルギーを吸収することで十分な安全性を確 保する設計が推奨されている。しかし、大きな「損傷の量」を許容 すること及び、全層への「損傷の広がり」が起こることで、過大な 修復費用が生じると同時に、修復に長期間を要することで機能回復 が困難となることが懸念されている。大地震時に建物に発生する損 傷を抑制し、社会に及ぼすダメージを小さくするためには、安全性 だけでなく、地震後の建物の機能回復性をも視野に入れた耐震設計 法の開発が求められる。

このような背景をもとに近年、機能回復に影響を及ぼす損傷の発 生量の推定法、また、損傷が発生した建物の修復性や地震後継続使 用性の評価法に関する研究が活発に行われている例えば2) 7)。

機能回復性を検討する際の評価項目として、修復費用と修復時間 がある。機能回復を考える上で損傷が引き起こす修復時間の評価は 極めて重要であるが、修復費用と比較し修復時間の観点からの損傷 評価を試みた研究は少ないのが現状である。

本論文では、安全性ではなく機能回復性の観点から損傷の深刻度 を評価する指標の提案を行う。すなわち、損傷の深刻度を修復時間 が相対的に大きくなることと定義し、安全性低下を引き起こす物理
的な損傷の大きさではなく、機能回復性を考える上で重要な修復時 間の観点から損傷の深刻度を評価する指標の提案を試みる。提案指 標は、耐損傷性能の確保を目標とした耐震設計法における目標性能 レベルの設定や確保された性能レベルの評価に用いられることを想 定している。ここで耐損傷性能とは、地震時の損傷の発生を抑制す ることにより建物の機能低下および機能回復期間を小さく抑える性 能である。

なお、提案する指標は、安全性能に対する損傷の深刻度評価を目 的としたものではないため、安全性に対する評価は、これとは別の 損傷指標（例えば、被災度区分判定における損傷度 ${ }^{8}$ )など）で行わ れる必要がある。

\section{2. 機能回復性の観点からの損傷の深刻度評価}

損傷指標の開発を行う上で評価対象とする要因とそうでないもの を区別し指標の位置づけを明確にすることは重要である。先に述べ たように、本研究では損傷の深刻度を修復時間が相対的に大きくな ることと定義する。以下では、一般的な工程計画策定手順 ${ }^{9)}$ を示し、 修復時間に影響を及ぼす要因を整理する。

修復工事は一般にいくつかの修復箇所および修復工法の工事から 成っている。工程表作成にあたりまず、これら工事毎の作業時間 $t$ を 次式で算出する。

$$
t=\frac{Q}{S \times E}
$$

ここに、 $Q$ : 施工数量、 $E$ : 能率定数、 $S:$ 作業部隊数である。施工数 量は工事毎に適切な単位で表された工事の量であり、例えば、コン
*1 東京理科大学理工学部建築学科 教授 · 工博

*2 国立研究開発法人建築研究所構造研究グループ 主任研究員・博士 (工学)
Prof., Dept. of Architecture, Faculty of Science and Engineering, Tokyo Univ. of Science, Ph.D. Senior Research Engineer, Dept. of Structural Engineering, Building Research Institute, Dr. Eng. 
クリート工事ではコンクリートの体積、鉄骨の建て方工事では鉄骨 重量が用いられる。また、能率定数は 1 作業部隊が 1 日に行える施 工数量である。

1 作業部隊を 1 日動かすために必要な労務量を $n$ として、この式 を次のように書き換えることができる。

$$
t=\frac{Q \times n / E}{n \times S}
$$

分子は 1 部隊で作業を行った場合の所要日数 $Q / E$ に 1 作業部隊を 1 日動かすに必要な労務量 $\mathrm{n}$ を乗じたものであり、これの意味する ものはこの修復工事に必要な労務量である。分母 $\mathrm{n} \times \mathrm{S}$ は、この工 事の実施のために投入される作業員の数である。すなわち、(2)式は 次のように書き換えられる。

$$
t=L i / m i
$$

ここに、 $L i$ : 作業 $i$ の労務量(人日)、 $m i$ : 作業員数(人)、である。こ こでの影響要因として、損傷の量、作業効率、そして、投入する作 業員数の決定方法の違いが挙げられる。

次に作業の順番、また、同時に行える作業かどうかを考えながら Fig.1(1)に示すネットワーク工程表 ${ }^{9)}$ を作成する。例として示した 工程の総労務量 $L_{T}(=\Sigma L i)$ は 70 人日であり、図中の矢印は 1 つの作 業を、また、これの上の数式は(3)式に基づく各作業の作業時間 $t$ の 算出式を意味している。矢印の始点と終点の数字はイベント番号と 呼ばれる通し番号である。ここでの影響要因として、各工事の実施 の順番に対する考え方の違い、損傷の発生している領域の広がり、 養生時間が必要となるかなどの損傷の質の違い、日曜・祝日や降雨・ 降雪などによる作業不能日、周辺環境に起因する作業時間帯の制限、 などが挙げられる。

最後に作成されたネットワーク工程表からクリティカルパスを確 認し、工期を算出寸る。Fig.1(1)の例ではクリティカルパスは(1)(3)(2) (4) (6) (8)の経路で生じており、工期はこの経路から決まる 10 日 $(=4+1+3+2)$ となる。また、工期中の作業員数等の変化を Fig.1(2)の ようにグラフ化し、投入される作業員数や資材量等が適切であるか 検討する。ここでの影響要因としては、社会的環境に起因する投入 可能な作業員数 - 資材量の制限や、建物所有者の希望する工期（指 定工期）などが上げられる。

以上をまとめると修復時間に影響を及ぼす要因として Table1 に 示寸 9 要因を挙げることができる。要因 I II III（「損傷の量」「広が り」「質」）は損傷状態に関する影響要因であるのに対して、要因IV $\sim \mathrm{IX}$ (IV.工事作業者の効率、 V.工程計画、VI. 指定工期、 VII. 作業 不能日、VIII. 周辺環境、 IX. 社会的環境）は損傷状態以外の影響要因 である。

本研究の目的は、建物に生じた損傷状態（要因 I II III）の深刻度 を、それに必要な修復時間を用いて評価する指標（損傷評価指標） を構築することである。実際の修復時間は、同じ損傷状態（ＩＩI III が同じ）であっても要因IV〜IXが異なれば異なったものとなり、こ れを損傷評価指標として使用寸ることはできない。なんらかの方法 によって要因IV〜IXの影響を排除した、評価対象である損傷状態(要 因 I II III)に対して一つの評価值を与える指標が必要である。次章以 降では、損傷状態以外の要因IV〜IXの違いが修復時間に及ぼす影響 を Table1 中に示した仮定を設けることによって排除した、損傷状 態に関する要因 I II IIIのみから決定される修復時間をもとに、損傷
の深刻度を相対的に評価する指標の構築を試みる。

\section{3. 部材の損傷評価}

前章で述べたように工程表の策定は、各部分の工事の作業時間の 評価と、これに基づく全体工期の評価の 2 段階で成っている。ここ でも、部材の評価(3.1で述べる時間損傷度の算出)とその結果に基づ く建物全体の評価(4.で述べる理想修復時間の算出)の、2 段階の損 傷評価を考えることにする。

\section{1 時間損傷度}

部材の修復時間は、同じ損傷状態でも修復条件（例えば、採用寸 る修復工法、投入する作業員数、作業効率等）によって異なってく る。本研究では、以下に定める標準的な修復条件のもとで計算され る部材 $\mathrm{i}$ の修復時間を時間損傷度 $t d i$ と呼ぶことにする。 $t d i$ は、 時間を用いて部材の損傷度を相対的に評価する一種の損傷評価指標 である。一般に修復条件は個々の現場で異なっており、tdi はそれ らの修復時間とは一致しないが、損傷状態に対応して生じる修復時 間の目安としては有効でる。

2 章で述べた工事毎の作業時間の算出式((3)式)を参考に部材 $i$ の 時間損傷度を次式で算出する。

$$
t d i=L i / m_{i}
$$

ここに、 $L i$ : 部材 $i$ の修復のために必要な労務量(人日)、 $m_{i}$ : 投入作 業員数(人)、である。 $m_{i}$ は部材 $i$ の修復作業のために必要となる床

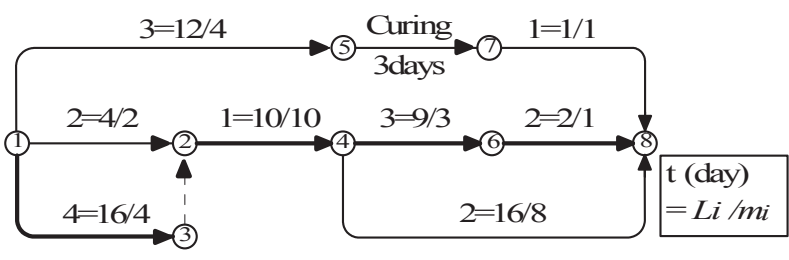

(1) Network time schedule $\left(L_{T}=70\right)$

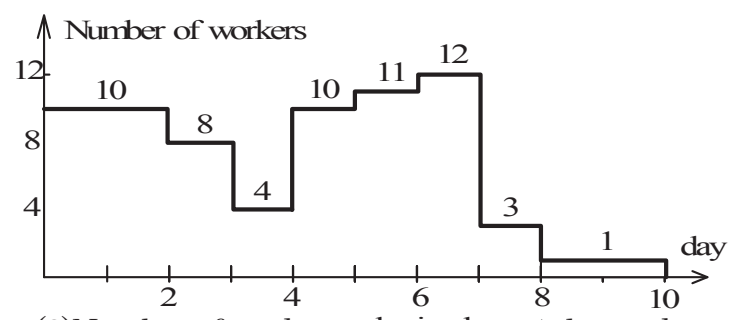

(2) Number of workers who implement the work Fig. 1 Process planning

Table 1 Influence factors on repair time, and assumptions

\begin{tabular}{|c|c|c|}
\hline & Influence factors on repair time & $\begin{array}{c}\text { Assumptions to eliminate } \\
\text { influence } \\
\text { by the factors }\end{array}$ \\
\hline I & Amount of damage & - \\
\hline II & Eextent of damage & - \\
\hline II & Quality of damage & $\begin{array}{c}\text { Difference in work efficiency that resulted from } \\
\text { adopted methods and worker proficiency }\end{array}$ \\
\hline V & $\begin{array}{c}\text { Approach to order of work and work performed } \\
\text { simultaneously }\end{array}$ & $\begin{array}{c}\text { Standard repair method and } \\
\text { work efficiency } \\
\text { workers (4.1) }\end{array}$ \\
\hline VI & $\begin{array}{c}\text { Difference in target repair time required by } \\
\text { building owner }\end{array}$ & No target by building owner \\
\hline VII & $\begin{array}{c}\text { Days when workers cannot work because of } \\
\text { holidays, rainfalls, and snow falls }\end{array}$ & $\begin{array}{c}\text { No days when workers } \\
\text { cannot work }\end{array}$ \\
\hline III & $\begin{array}{c}\text { Limitation on the working time depending on } \\
\text { the surrounding environment }\end{array}$ & No limitation \\
\hline IX & $\begin{array}{c}\text { Limitation on the number of workers and the } \\
\text { amount of materials depending on the social } \\
\text { environment. }\end{array}$ & No limitation \\
\hline
\end{tabular}


面積 $a_{i}$ （以下、修復作業面積）から次式で算出する。

$$
m_{i}=a_{i} \times k_{1}
$$

$k_{1}$ は修復作業面積 $1 \mathrm{~m}^{2}$ あたりに投入可能な最大作業員数を定め る定数である。公共建築改修工事の積算マニュアル 10$)$ には修復工 事を行うにあたり修復対象物から $1 \mathrm{~m}$ 離して仮設間仕切りを設け 作業エリアを確保することが示されている。Fig.2 に示すような壁 面修復を行う場合を想定し、壁から $1 \mathrm{~m}$ の帯状のエリアに作業員が 並び修復工事を行う場合、作業の干渉が起こらない最小の作業員間 隔として、作業員が両手を広げた $2 \mathrm{~m}$ 程度から、両肘を広げた $1 \mathrm{~m}$ 程度が考えられる。ここでは、これらの内、小さい方の、作業員が 両肘を広げた幅 $1 \mathrm{~m}$ と、壁からの距離 $1 \mathrm{~m}$ を乗じた $1.0 \mathrm{~m}^{2}$ の床面積 に一人を、投入可能最大作業員数と仮定し、 $k_{I}=1.0$ 人 $/ \mathrm{m}^{2}$ を用い ることとした。

また、上で述べた公共建築改修工事の積算マニュアルを参考に原 則として、修復対象面から $1 \mathrm{~m}$ 離して平行線をとり、これらによっ て囲まれる面積から修復対象物の存在する面積を除いた面積を修復 作業面積 $a_{i}$ とすることとした。柱部材および梁部材における修復作 業面積の計算例を Fig. 3 に示した。なお、梁部材の場合には、両端 で柱と接しているため作業面積は 4 周とならないこと、一方、部材 直下の床面積は修復作業面積に含まれること、が柱部材と異なって いる。

部材 $i$ の必要労務量 $L i$ は、発生した各種の損傷の修復に必要な労 務量を総和することにより次式で算出される。

$$
L i=\Sigma\left(Q_{j} \times \beta_{j}\right)
$$

ここに、 $\beta$ は修復時間係数であり、建築研究所の研究プロジェクト 4) において、構造部材・非構造部材・設備機器に発生する損傷に対 する各種修復工事の $\beta$ が調查され、修復性評価データベースにまと められている。例として、修復性評価データベースにある、ひび割 れ幅「 $0.2 \mathrm{~mm}$ 未満」「 $0.2 \mathrm{~mm}$ 以上」、及び、コンクリートの「剥落」 の 3 種の損傷の $\beta$ を Table 2 に示寸。なお、ひび割れ幅「 $50.2 \mathrm{~mm}$ 未

Table 2 Repair time coefficient $\beta$

\begin{tabular}{|c|c|c|}
\hline Types of damage & Amount of repair work & $\begin{array}{c}\text { Repair time } \\
\text { coefficient } \beta\end{array}$ \\
\hline Width of crack less than $0.2 \mathrm{~mm}$ & Length of crack $Q_{A}(\mathrm{~m})$ & $\beta_{\mathrm{A}}=0.03$ \\
\hline Width of crack 0.2 mm or more & Length of crack $Q_{B}(\mathrm{~m})$ & $\beta_{\mathrm{B}}=0.24$ \\
\hline Spalling of concrete & Area of spalling $Q_{C}\left(\mathrm{~m}^{2}\right)$ & $\beta_{\mathrm{C}}=7.1$ \\
\hline
\end{tabular}

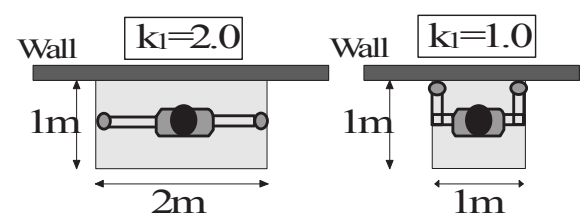

Fig. 2 Minimum Work Area and Coefficient $k_{1}$

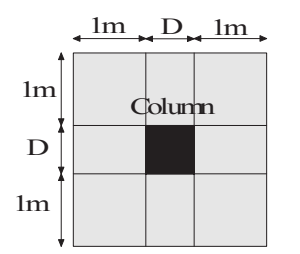

$a=(2+\mathrm{D}) \times(2+\mathrm{D})-\mathrm{D}^{2}$

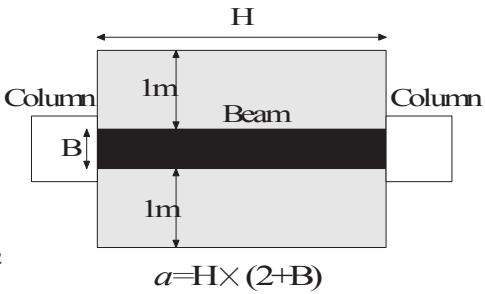

$a=\mathrm{H} \times(2+\mathrm{B})$
Fig.3 Repair Work Areas of Column and Beam Members 満」と「0.2mm 以上」で $\beta$ の値が違っているのは、修復工法が前者 はシール工法、後者はエポキシ樹脂注入工法と異なってくるためで ある。これらを用いて(6)式を具体的に記述すると次式となる。

$$
L i=Q_{A}(m) \times \beta_{A}+Q_{B}(m) \times \beta_{B}+Q_{C}\left(m^{2}\right) \times \beta_{C}
$$

\section{2 エリア時間損傷度}

時間損傷度 $t d i$ の部材が存在するということは修復作業面積 $a_{i}$ が $t d i$ の間、修復のため使用不能となることを意味している。複数の 部材が存在すると使用不能となるエリアが増加し、かつ、 $a_{i}$ の重複 するエリアでは修復時間も長くなる。この修復時間を平面図中に示 したものをエリア時間損傷度 $t d A$ 分布と呼ぶことにする。平面上の 各点の $t d_{A}$ は次式で計算される。

$$
t d_{A}=\sum_{i=1}^{n} t d i
$$

ここに、 $n$ :その位置を修復作業面積に含む部材の数、である。Fig.4 は建物内に時間損傷度が $t d_{1}, t d_{2}, t d_{3}$ の 3 つの部材が存在するケ

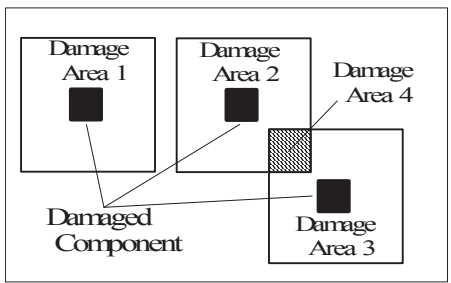

\begin{tabular}{c|c|c} 
& $\mathrm{td}_{\mathrm{A}}$ & ${ }_{\mathrm{R}} \mathrm{A}$ \\
\hline $\begin{array}{r}\text { Damage } \\
\text { Area 1 }\end{array}$ & $\mathrm{td}_{1}$ & $\mathrm{a}_{1}$ \\
\hline $\begin{array}{r}\text { Damage } \\
\text { Area 2 }\end{array}$ & $\mathrm{td}_{2}$ & $\mathrm{a}_{2}$ \\
\hline $\begin{array}{r}\text { Damage } \\
\text { Area 3 }\end{array}$ & $\mathrm{td}_{3}$ & $\mathrm{a}_{3}$ \\
\hline $\begin{array}{r}\text { Damage } \\
\text { Area 4 }\end{array}$ & $\mathrm{td}+\mathrm{td}_{3}$ & $\mathrm{a}_{4}$
\end{tabular}

Fig.4 Distribution of area time damage tdA

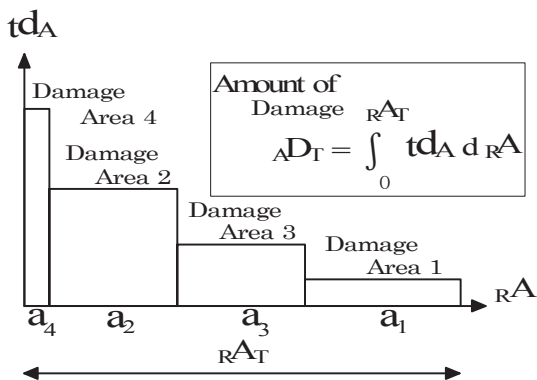

(1) Relation of $t d A$ and $R A$

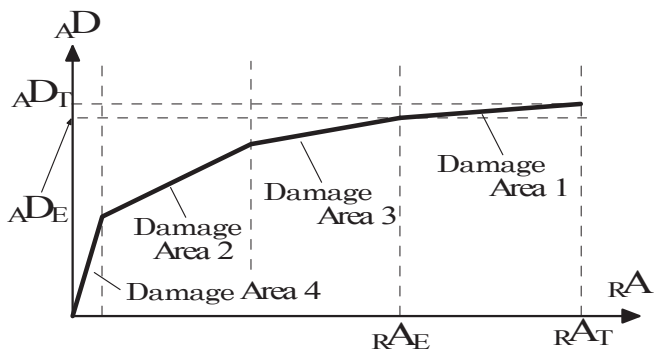

(2) Relation of $A D$ and $R A$

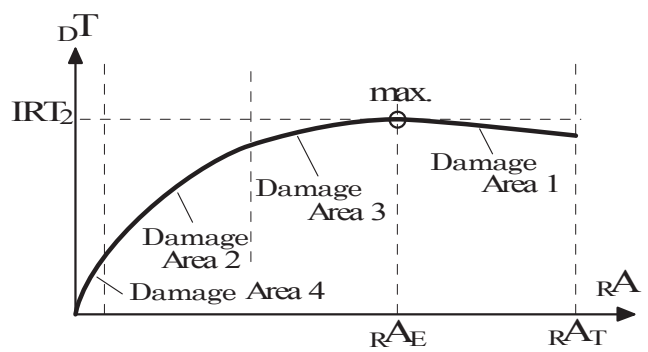

(3) Relation of $D T$ and $R A$

Fig.5 Calculation Procedures of IRT2 


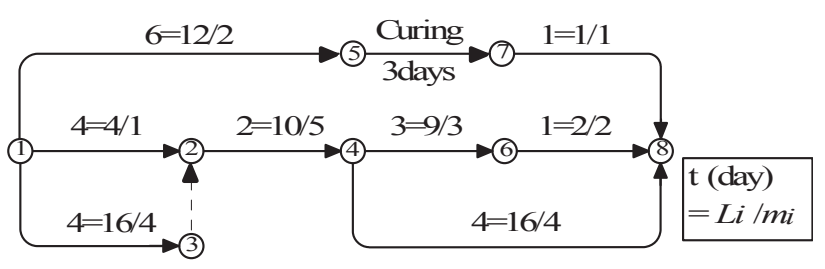

(1)Network time schedule $(L T=70)$

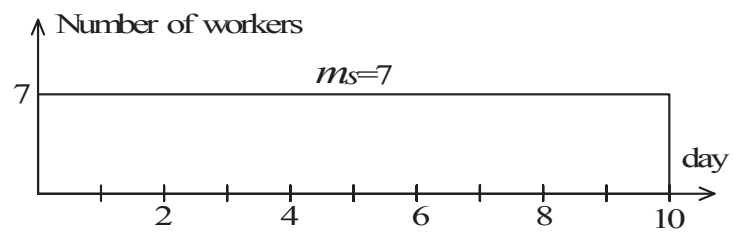

(2)Number of workers who implement the work

Fig.6 Process Planning

一スにおける $t d A$ 分布を模式的に示したものである。重複があるた め $t d_{A}$ が同じとなる 4 つのエリア (以下、各エリアを「損傷エリア」 と呼ぶ）が生じており、これらのエリア時間損傷度 $t d A$ および面積 (以下、 $R A$ ） は図中の表に示すようになる。

Fig.5(1)は横軸に $R A$ を取り各損傷エリアの $t d A$ を大きい順に並べ たものである。この $t d_{A}-R A$ 関係を $R A$ について積分したものを時間 損傷量 $A D$ と呼ぶ。(4)(5)(8)式から $A D$ は次式で与えられる。ここに、 $L$ は $R A$ 内の修復工事の労務量(人・日)である。横軸に $R A$ 、縦軸に ${ }_{A} D$ を取り示すと Fig.5(2)に示す $A D-R A$ 関係が得られる。

$$
{ }_{A} D=\int_{0}^{R A}\left(t d_{A}\right) d R A=L / k_{1}
$$

各損傷エリア $R A$ の総和を総損傷エリア $R A T$ と呼ぶ。また、 Fig.5(1)に示した $t d_{A}-R A$ 関係を次式に示すように 0 から $R A T$ に渡っ て積分したものを総時間損傷量 $A D T$ と呼ぶ。

$$
{ }_{A} D_{T}=\int_{0}^{R A_{T}}\left(t d_{A}\right) d_{R} A=L_{T} / k_{l}
$$

ここに、 $L_{T}$ は $R A T$ 内の修復工事の労務量 (総労務量) (人・日)である。

\section{4. 理想修復時間 $I R T$}

理想修復時間 IRT は、Table 1 に挙げた修復時間に影響を及ぼす要 因のうち、損傷状態以外の要因IV〜IXについて表中に示した仮定を 設けることによって、それらが生じさせる相対差を排除した修復時 間である。ここで、「理想」という用語は、最高の状態の意味ではな く、ある条件（上記の仮定）を満足するという意味で用いている。

$I R T$ は次に述べる $I R T_{1} 、 I R T_{2} 、 I R T_{3}$ の中の最大值で求められる。 $I R T_{1}$ は損傷の量から決まる修復時間、そして、IRT 2 は損傷の広がり から決まる修復時間である。また、IRT3 3 損傷の質が異なるために これら $I R T_{1} 、 I R T_{2}$ で評価できない修復時間である。IRT $T_{1} I R T_{2} 、 I R T_{3}$ 、 はそれぞれ先に述べた要因 I , II, III と対応する修復時間である。

\section{1 修復時間の定式化}

工事現場の作業員数は、施工効率や経済性の観点から決定されて いる。施工実態から標準的と考えられる作業員数を標準作業員数 $m_{s}$ と定義する。Fig.1(1)(2)に工程表の例とそれに対応する作業員 数の変化を示した。この図に示すように一般的に工期中の作業員数 は変化するが、Fig.6(2)に示すように作業員数が標準作業員数 $m_{s}$ で

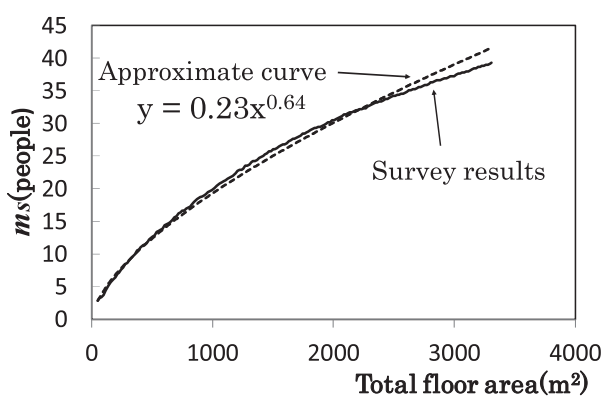

(1) Carpenter work

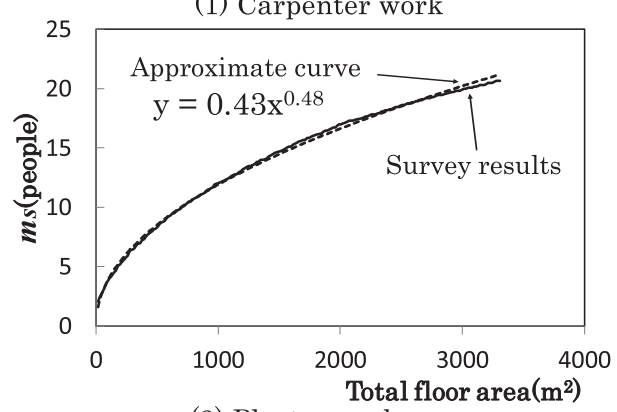

(2) Plaster work

Fig.7 Standard Number of Workers $m s$ and Total Floor Area ${ }^{11)}$

一定となる場合には、Fig.6(1)のような工程表の作成なしに総労務 量 $L_{T}$ から (11)式を用いて工期を算出することができる。Fig.6 の例 では $L_{T}=70$ 人日、 $m_{s}=7$ 人であるので、Fig.6(1)の工程表から得 られているのと同じ工期 10 日（クリティカルパス(1)(3)(2)(4)(6)(8)の (4+2+3+1=10)を 70/7 の計算で算出することができる。

$$
T=\frac{L_{T}}{m_{S}}
$$

この場合、養生時間を計算に入れずに工期が算出可能であること に注意が必要である。これは、養生時間中も作業員は他の作業を行 うことができ、標準作業員数 $m_{s}$ の作業員が工期中に不断無くなん らかの作業を行うことができることを仮定しているためである。な お、工期中の作業員数が一定でなくても、工期中の平均作業員数 $(=L T / T)$ が $m_{s}$ と一致する場合には(11)式は有効である。

上で述べたように、要因 V が修復時間に及ぼす影響を排除する目 的で、 $m_{s}$ が全工期に渡って平均的に投入されるとする仮定（すな わち、全ての工事の順番を自由に変えられ、また、同時に行えると する仮定）をおくと、ネットワーク工程表を作成し求められる工期 は、(11)式で算出した工期と一致する。このことは、要因 V の影響を 排除した場合において(11)式は、一般に実務で用いられているネッ トワーク工定表と同じ工期を与える、信頼性のある算出式となって いることを示している。

笹間 11) は木造 1 ・ 2 階建物の建設工事における大工工事・左官 工事の標準作業員数について、それぞれ専門家 10 人ずつに対して アンケート調查を行い、Fig.7 に示す、建設する建物の延床面積 $A$ と 標準作業員数 $m_{s}$ の関係を導き出している。図中に、(12)式の形を仮 定し得られた近似曲線を示した。なお、式中の $\lambda_{1}, \gamma$ は定数である。

$$
m_{s}=\lambda_{I} \times A^{\gamma}
$$

Fig.7 から、(12)式の形を用いることで延床面積 $A$ と標準作業員 数 $m_{s}$ の関係を精度よく表現できていることが分かる。これら近似 
曲線における $\gamma$ の值は、大工工事で 0.64 、左官工事で 0.48 である。 本研究ではこれらを参考に以降では $\gamma$ の值を 0.5 と仮定し定式化を 進める。

なお、この調査研究は近年のものではなく、また、当時の手作業 を主とした工事を前提としているが、次の理由で本研究の $\gamma$ 值の設 定の参考にしてよいと考えた。1.修復工事は建設工事と比較し重機 の使用が少ない手作業が主となる工事である。2.作業面積や工事量 に対して定まる適切な作業員数は当時も今もさほど変わらない。

(12)式で示されるように、建設する建物の延床面積 $A$ の増加に伴 い標準作業員数が増加する理由として次の 2 つが考えられる。

理由 1. 延床面積 $A$ の増加は工事量の増加を意味し、工事量に見 合った作業員数を投入する必要性から $m s$ が増加する。

理由 2. 延床面積 $A$ の増加によって作業スペースが大きくなり、

投入可能となる作業員数 $m_{s}$ が増加する。

まず「理由 $1 」$ の場合について考える。建設工事における単位延 床面積あたりの労務量を $k_{2}$ とすると、総労務量 $L T$ は次式で表現で きる。

$$
L_{T}=A \times k_{2}
$$

(11) 式から分かるように、投入作業員数 ( (11) 式の分母)を大きく すれば工期は短くなるが、多くの職人を集め一日未満、例えば半日 の作業とすることは職人のスケジュールの合理性の観点から普通は 考えにくい。そこでここでは、工事の量の観点から決まる最大の作 業員数 $m_{M I}$ は、(11) 式で $T=1$ 日とすることのできる作業員数と考 えることにした。よって、 $m_{M 1}$ は次式で表現される。

$$
m_{M I}=L_{T}=A \times k_{2}
$$

この関係を用いて(12)式の $A$ を消去すると、

$$
m_{s}=\frac{\lambda_{1}}{k_{2} \gamma} m_{M 1} \gamma
$$

$m_{s}$ と $m_{M l}$ の間には $1 \leq m_{s} \leq m_{M l}$ の関係があり、かつ、 $m_{M l}=1$ の とき $m_{s}=1$ であることから、上式は次のようになる。

$$
m_{s}=m_{M}{ }^{\gamma}=L T^{\gamma}
$$

この式を導き出す際に用いた標準作業員数算出の考え方は、建設・ 修復の違いに関わらず総労務量 $L T$ の工事に対して成り立つもので ある。(10)式から、労務量 $L T$ は本質的に総時間損傷量 $A D T$ と同じも のであり、(16)式で算出される $m_{s}$ は損傷の量から定まる標準作業 員数であると言う事ができる。

次に「理由 $2 」$ の場合であるが、この考えは、建設工事では作業 スペース $A w$ が延床面積 $A$ とともに増加すること（すなわち(17)式 の関係 $(C 1$ は定数) ) を仮定すると、(17)式と(12)式から標準作業員 数 $m_{s}$ が作業スペース $A w$ を用いて(18)式の形で表現できることに 因っている。

$$
\begin{aligned}
& A w=A \times C_{1} \\
& m_{s}=\frac{\lambda_{1}}{C_{I}{ }^{\gamma}} A w^{\gamma}=\lambda_{2} \times A w^{\gamma}
\end{aligned}
$$

この関係が修復作業の場合にも成り立つと仮定すると、3.2 節で 定義した、損傷修復に必要な作業スペースである損傷エリア $R A$ で (18)式の $A w$ を置き換えた(19)式を得ることができる。

$$
m_{s}=\lambda_{2} \times_{R} A^{\gamma}
$$

一方、 3.1 節で述べた係数 $k_{1}$ （修復作業面積 $1 \mathrm{~m}^{2}$ あたりに投入可 能な最大作業員数を定める係数）を用いると、施工効率や経済性は 考えず単純に物理的に考えて損傷エリア $R A$ 内に配置できる最大の 作業員数 $m_{M 2}$ を次のように求めることができる。

$$
m_{M 2}={ }_{R} A \times k_{1}
$$

この式と(19)式から、

$$
m_{s}=\frac{\lambda_{2}}{k_{1}{ }^{\gamma}} m_{M 2}{ }^{\gamma}
$$

$m_{s}$ と $m_{M 2}$ には $1 \leq m_{s} \leq m_{M 2}$ の関係があり、かつ、 $m_{M 2}=1$ のとき $m_{s}=1$ であることから、上式は次のようになる。

$$
m_{s}=m_{M 2^{\gamma}}=\left(R A \times k_{1}\right)^{\gamma}
$$

(22)式で算出される $m_{s}$ は「損傷の広がり」から定まる標準作業員 数である。

4.2 損傷の量と広がりから定まる修復時間 $I R T_{1}, I R T_{2}$

(11)式に、損傷量から定まる標準作業員数である(16)式を代入し、 (10)式の関係および $\gamma=0.5$ を用いれば、損傷の量から定まる修復時 間 $I R T_{1}$ が次式で算出される。

$$
\operatorname{IRT} T_{I}=\left({ }_{A} D_{T} \times k_{l}\right)^{l-\gamma}=\sqrt{{ }_{A} D_{T} \times k_{l}}
$$

次に損傷の広がりから定まる修復時間 $I R T_{2}$ について考える。損傷 エリア $R A$ 内に労務量 $L$ が存在する場合の修復時間 $D T$ は、(11)式の 考え方と、損傷の広がりから定まる標準作業員数(22)式および(9)式 の関係および $\gamma=0.5$ を用いて次式で算出される。

$$
D T=\frac{L}{\left(k_{1} \times{ }_{R} A\right)^{\gamma}}={ }_{A} D \frac{k_{I}^{(1-\gamma)}}{R A^{\gamma}}={ }_{A} D \sqrt{\frac{k_{1}}{{ }_{R A}}}
$$

Fig.5(2)に示した ${ }_{A} D-R A$ 関係の縦軸 $A D$ を、(24) 式を用いて $D T$ に 変換し得られる $D T-R A$ 関係を、模式的に示したのが Fig.5(3)であ る。この模式図に示すように ${ }_{D} T$ は必ずしも単調増加とはならず $R A$ が増加するにも関わらず減少するケースが生じうる。Fig.5(3)の例 では損傷エリア $4 \cdot 2 \cdot 3$ では増加しているが損傷エリア 1 が追加され ると ${ }_{D} T$ は減少に転じている。これは損傷エリア 1 が追加されるこ とによる ${ }_{A} D$ 増よりも、 $R A$ 増による $m_{s}$ 増が大きくなるために生じ る。

しかし、実際の修復では損傷エリア $2 \cdot 3 \cdot 4$ の修復時間よりも損傷 エリア $1 \cdot 2 \cdot 3 \cdot 4$ の修復時間が短くなることはありえない。実際には 損傷エリア 1 を別工事とし損傷エリア $2 \cdot 3 \cdot 4$ の修復作業中に損傷エ リア 1 の工事を終了させる。つまり、損傷エリア 1 の ${ }_{A} D$ 及び $R A$ は ${ }_{D} T$ の増加に影響を及ぼさない。

そこで、 $R A T$ から損傷エリア 1 の $R A$ を差し引いて求められる有効 損傷エリア $R A E$ とその時の時間損傷量 $A D E$ （以下、これを有効時間 損傷量）を用いて (24)式を書き直した次式で $I R T_{2}$ を算出する。損傷 の広がりから定まる修復時間 $I R T_{2}$ は、 $D T-R A$ 関係における $D T$ の 最大值として求められる。

$$
\operatorname{IRT} 2={ }_{A} D E \sqrt{\frac{k_{1}}{R A e}}
$$




\section{3 損傷の質から定まる修復時間 $I R T_{3}$}

修復時間は 2 種類の時間で構成されている。1つは「作業時間」 であり、もう一つは「待ち時間」である。作業時間は、修復にあた って作業員が作業を行うために必要な時間であるのに対して、待ち 時間は、作業員は作業を行わないが修復を進めるにあたって必要と なる時間である。待ち時間の例として、コンクリート養生期間や、 注文生産となる資材における製作から納品までの時間などがある。

作業時間は作業員数を増やすことによって短縮することが可能で あるが、待ち時間は投入される作業員数で短縮することができない。 両者は性質の異なる時間であるといえる。先に述べた $I R T_{1}, I R T_{2}$ は、 標準作業員数 $m s$ の作業員が工期中に不断無くなんらかの作業を行 うことができ、待ち時間と関係なく(11)式で修復時間が計算できる ケースの修復時間である。

待ち時間のために、作業員が作業を行えない時間帯（遊びの時間 帯）が生じ、修復時間が(11)式で計算できないケースを考える。この ようなケースにおける修復時間 $\left(I R T_{3}\right)$ は、待ち時間を必要とするある 特定箇所の修復作業がクリティカルパスとなり、その部分の修復時 間で決定される。すなわち、IRT 3 は、各部分の修復時間（部分修復 時間 $P T$ ) を待ち時間も含めた $(26)$ 式で計算し、そのうちの最大值 ((27)式) で算出することになる。

$$
\begin{gathered}
P T=t d_{A}+\sum_{i=1}^{n_{y}} y_{i} \\
I R T_{3}=\max \{P T\}
\end{gathered}
$$

ここに、 $n_{y}$ : その部分の修復に必要となる待ち時間の種類数、 $y_{i}:$ $i$ 番目の待ち時間 (養生時間や資材納品待ちの時間等)の長さ、 $t d A$ :
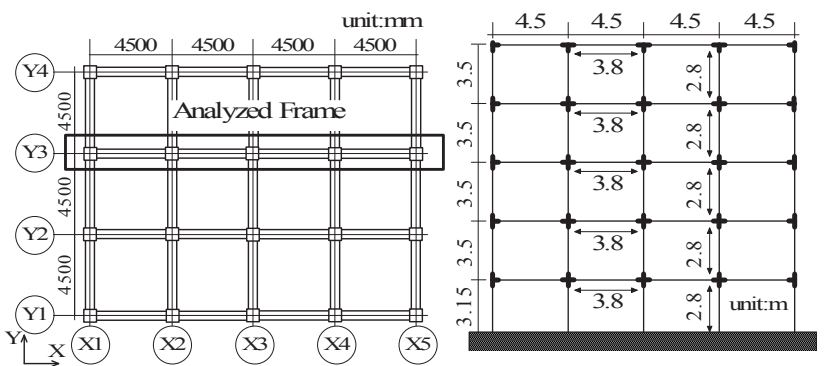

Fig. 8 Analyzed Building

Table3 Analysis Case and IRT

\begin{tabular}{|c|c|c|c|c|}
\hline Analysis Case & S-3 & S-7 & S-15 & S-31 \\
\hline $\begin{array}{c}\text { Number of spans } \\
\text { in Y direction }\end{array}$ & 3 & 7 & 15 & 31 \\
\hline Total Floor Area $\left(\mathrm{m}^{2}\right)$ & 1215 & 2835 & 6075 & 12555 \\
\hline $\mathrm{IRT}^{\text {(day) }}$ & 26.4 & 37.3 & 52.7 & 74.5 \\
\hline $\mathrm{IRT}_{1}$ (day) & 26.4 & 37.3 & 52.7 & 74.5 \\
\hline $\mathrm{IRT}_{2}$ (day) & 25.3 & 35.7 & 50.6 & 71.5 \\
\hline
\end{tabular}

\begin{tabular}{|c|c|c|c|c|c|c|}
\hline & \multirow{2}{*}{$\begin{array}{l}\text { Width } \times \text { Depth } \\
(\mathrm{mm} \times \mathrm{mm})\end{array}$} & \multicolumn{2}{|c|}{$\begin{array}{c}\text { Longitudinal } \\
\text { Reinforcement }\end{array}$} & \multicolumn{2}{|c|}{$\begin{array}{c}\text { Shear } \\
\text { Reinforcement }\end{array}$} & \multirow{2}{*}{$\begin{array}{l}\text { Concrete } \\
\text { Strength }\end{array}$} \\
\hline & & $\begin{array}{l}\text { Diameter } \\
\text { \&Quantity }\end{array}$ & $\sigma y$ & $\begin{array}{l}\text { Diameter } \\
\text { \&Spacing }\end{array}$ & $\sigma y$ & \\
\hline Beam & $500 \times 700$ & $\begin{array}{c}\text { top: } 5-\mathrm{D} 25 \\
\text { bottom:3-D25 }\end{array}$ & $\begin{array}{c}380 \\
\left(\mathrm{~N} / \mathrm{mm}^{2}\right)\end{array}$ & $\begin{array}{l}3-\mathrm{D} 13 \\
\text { @ } 100\end{array}$ & $\begin{array}{c}295 \\
\left(\mathrm{~N} / \mathrm{mm}^{2}\right)\end{array}$ & $\begin{array}{c}30.0 \\
\left(\mathrm{~N} / \mathrm{mm}^{2}\right)\end{array}$ \\
\hline Column & $700 \times 700$ & $16-\mathrm{D} 25$ & $\begin{array}{c}380 \\
\left(\mathrm{~N} / \mathrm{mm}^{2}\right)\end{array}$ & $\begin{array}{l}\text { 4-D13 } \\
\text { @ } 100\end{array}$ & \begin{tabular}{|c|}
295 \\
$\left(\mathrm{~N} / \mathrm{mm}^{2}\right)$ \\
\end{tabular} & $\begin{array}{c}30.0 \\
\left(\mathrm{~N} / \mathrm{mm}^{2}\right)\end{array}$ \\
\hline
\end{tabular}

Table4 Details of Analyzed Building
エリア時間損傷度（3.2 節）である。

\section{5. 梁崩壊形建物を対象とした損傷度分析}

\section{1 解析対象建物および解析方法}

解析対象建物は Fig.8 に示寸 5 層の R C フレーム構造である。各 階の柱及び梁のクリアスパンはそれぞれ $2.8 \mathrm{~m}$ と $3.8 \mathrm{~m}$ である。解 析方向であるX方向のスパン数は 4 、そして、Y方向のスパン数は 3 である。これを基本モデルとしてY方向のスパン数を $3,7,15,31$ と 変えた合計 4 ケースについて解析を行った（Table3）。以下ではこれ らをそれぞれ、解析ケース S-3,7,15,31 と呼ぶことにする。柱およ び梁の寸法及び配筋を Table4 に示した。

解析は外力分布に Ai 分布を用いた一方向載荷解析である。いず れかの層の層間変形角が $1 / 50$ に達した時点で解析を打ち切り、その 時点での損傷度分析を行った。解析には構造計算プログラム SNAP を用いた。柱及び梁部材は材端弾塑性ばね法によって線材でモデル 化した。柱部材は曲げばね、せん断ばね、軸ばねを有し、梁部材は 曲げばねとせん断ばねを有する。柱梁接合部の剛域はフェイス位置 とした。

\section{2 損傷状態と時間損傷度}

Fig.9(1)に解析から得られた各層の層せん断力と層間変位の関係 を示す。 $1 \cdot 2 \cdot 3$ 層の変形が大きくなっていることが分かる。 Fig.9(2)に曲げ降伏ヒンジの発生位置および各部材の時間損傷度 $t d i$ を示す。 $t d i$ は 1 ・ 2 層の梁で大きく、次に 3 層の梁と 1 層の 柱、そして、4 層の梁がこれに続いている。 $t d i$ の值から、例えば 1 ・ 2 層の梁では、 1 部材あたり 1.3 日の修復時間が必要であるの に対して、1 層の柱では 0.5 日、 4 層の梁では 0.3 日が必要となる ことが分かる。損傷の程度を時間損傷度 $t d i$ で表現することによっ て、特別な専門知識のない人でも建物の各所に発生する損傷の深刻 度のイメージを知ることが可能である。
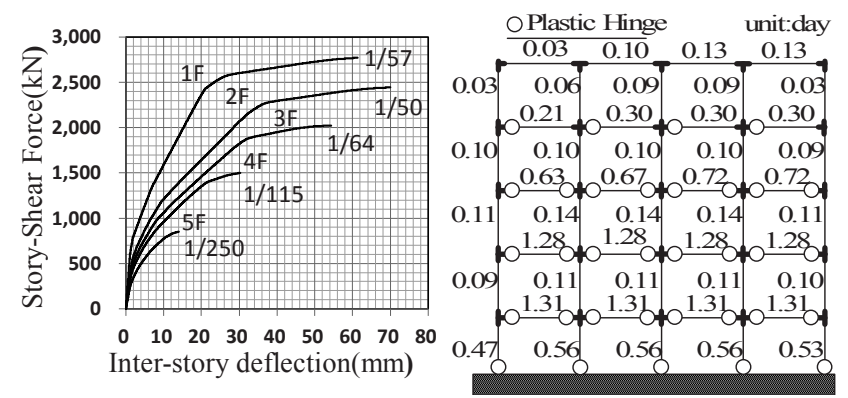

(1) Inter-story deflection of each story (2) $t d i$ of each member Fig. 9 Damage State and Time damage $t d i$

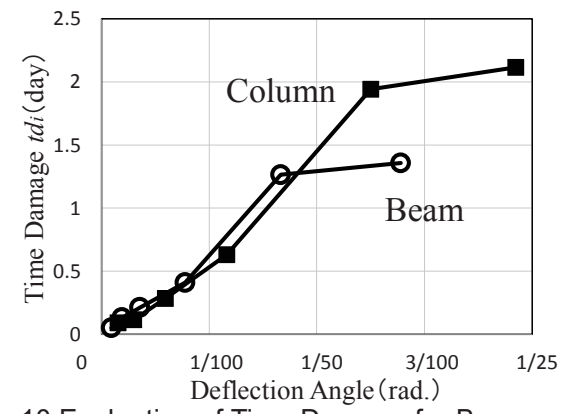

Fig.10 Evaluation of Time Damage for Beam and Column 


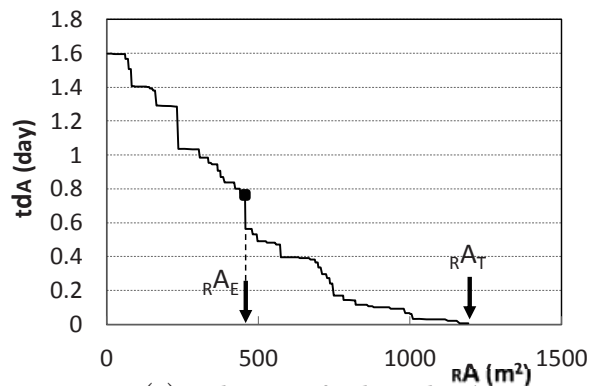

(1) Relation of $t d A$ and $R A$

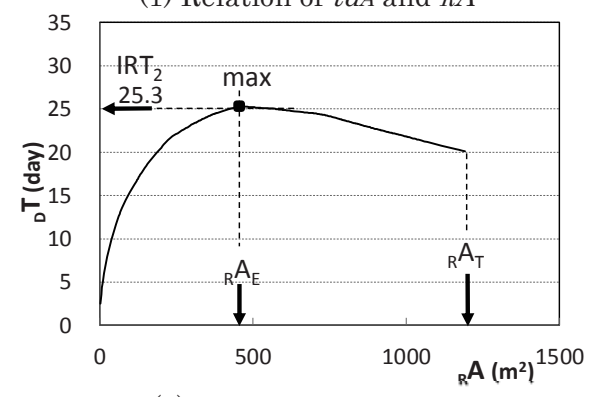

(2) Relation of $D T$ and $R A$

Fig. 11 Calculation of IRT2

なお、柱部材・梁部材の損傷度評価は文献 12)に示されている架 構実験の柱および梁部材について、(4)〜 (7)式を用いて算出した時間 損傷度 $t d i$ (Fig.10) に基づき行った。具体的には、解析で得られた 部材角に対応寸る各部材の $t d i$ を Fig.10から読み取り使用した。既 往の研究例えば 2 I 3) において、鉄筋コンクリート部材に発生する損 傷量（ひび割れ長さや剥落量等）は主に、シアスパン比・軸力比・ 破壊モードに影響を受けることが指摘されている。文献 12)の実験 データを用いたのは、破壊モードが曲げ破壊で、かつ、シアスパン 比・軸力比が解析フレームのものと大きく違わないからである。

\section{3 理想修復時間 IRTの算出}

基本モデルである解析ケース S-3 の IR $T_{2}$ の算出過程を Fig. 11 に 示す。Fig.11(1)(2)はそれぞれ先に述べた Fig.5(1)(3)に対応する。 ${ }_{D} T-R A$ 関係の Fig.11(2)から、 ${ }_{D} T$ の最大值は 25.3 日となってお り、損傷の広がりから決定されるIRT 2 は 25.3 日ということになる。 また、総時間損傷量 $A D T$ は 694.6 (日 $\mathrm{m}^{2}$ ) であり、(23) 式を用いると 損傷の量から決定されるIRT 1 は 26.4 日となる。なお、この修復に おける養生は、夜間を利用して終了寸る程度のものしか存在せず、 工程上の「待ち時間」は発生しない。従って、IRT $T_{3}$ 算出の必要は ない。

以上のことから、IRT 1 が $I R T_{2}$ より大きく、IRT は $I R T_{1}$ の 26.4 日 で決定される。同様にして得られた、解析ケース S-3,7,15,31のIRT 、 $I R T_{2}$ および、IRT の值をまとめて Table3 に示した。

\section{6. 理想修復時間 IRTの妥当性および有用性の検討 \\ 6.1 損傷の量と広がりに対する定性的評価}

全体崩壊形は高い安全性を実現できる一方で、損傷を建物全体に 分散させるため、大きな損傷の「量」および「広がり」を許容する。 提案指標は、これらが引き起こす相対的な深刻度の増加（修復時間 の増加）を適切に評価できるものである必要がある。

修復時間は Table1 に示した要因 I 〜 IX（損傷状態に関寸る要因 I II III とそれ以外の要因IV〜IX）の影響を受ける。IRT は要因 I II
IIIから決定される修復時間であり、実被害建物の修復時間（以下、 「実修復時間」と略記）とは異なってくる。このため、実修復時間 との単純な比較から、IRTの、損傷の「量」および「広がり」に対す る評価の妥当性を検証することは難しい。例えば、実修復時間の要 因分析を行い、要因 I II IIIが修復時間に及ぼす影響量を抽出するな どすれば、その結果を用いて IRTの妥当性検証が可能になると思わ れるが、実修復時間のデータは多くなく現時点では困難である。

一方、建物建設時の工期データは豊富であり、文献 13)には、平均 的な状況を仮定した場合の工期である標準工期 $T$ が、延床面積 $A$ と 次式の関係にあることが示されている。

$$
T=\lambda_{3} \times A^{\eta}
$$

この式から、延床面積 $\mathrm{A}_{0}$ の建物の工期 $\mathrm{T}_{0}$ と、延床面積 $\mathrm{A}$ の建物の 工期 $\mathrm{T}$ との比を次式のように計算することができる。 タにとり(29)式をグラフ化したものが Fig.12である。

$$
\frac{T}{T_{0}}=\left(\frac{A}{A_{0}}\right)^{\eta}
$$

一般的に $\eta$ は 0 以上 1 以下の範囲の值を取る。Fig.12 から分かる ように $\eta=1$ は、延床面積 $\mathrm{n}$ 倍（すなわち、工事量 $\mathrm{n}$ 倍）になると $\mathrm{n}$ 倍の工期が必要となるケース、 $\eta=0$ では延床面積が大きくなっ ても、効率的な工程計画等によって工期の増加を抑えることのでき るケースに対応している。

文献 13)には建設工事における $\eta$ の值が建物用途によって 0.09〜 0.4 の範囲となることが示されている。建物建設における延床面積 $A$ の増加は工事の量・広がりの増加であることから(29)式は工事の 量・広がりと工期の一般的な関係を示したものと言える。

修復も工事の一種と考えると、損傷の量と広がりの増加は、工事 の量と広がりの増加と見ることができる。同じ被災度であれば延床 面積の大きい建物の、損傷の量と広がりは大きくなると考えると、 修復時間も損傷を受けた建物の延床面積と、(28)(29)式と同様の関 係にあることが推察される。実際、諏訪 14) は、兵庫県南部地震にお ける実修復時間についての分析を行い、建設工期と比べてデータ数 は少ないものの、それらから (28)式と同様の関係式を見い出してい る。そこにおける $\eta$ の值は、大破で 0.49 、中破で 0.38 である（大・ 中破は被災度区分判定基準 8)の被災度ランク)。

以上のことからここでは、損傷の量と広がりに対するIRT の評価 の妥当性を、建設工事において一般的に見い出され、また、修復工 事でも傾向が確認されている、(28)(29)式をもとに検討を行うこと にする。具体的には、延床面積の異なる複数の建物のIRT を算出し、 延床面積とIRT の関係が(28)式の傾向を表現しうるものになるか、 また、その時の $\eta$ の值が妥当な数值となりうるか、を見てみること に寸る。(29)式から $\eta$ は本研究の評価目標である修復時間の相対比 較を考える上で重要な係数であることが分かる。

先に述べた一般の建設工事 13) と、実際の修復工事 14)における曲線 を Fig.12 中に示した。中破で、一般の建設工事の上限と同程度、大 破では、建設工事の上限を越えてしまっている。大破で $\eta$ が大きく なるのは、中破と比べて相対的に効率的な工事計画が困難となるた めと推察される。

$\mathrm{Y}$ 方向のスパン数を増加させ延床面積を変化させた各解析ケース S-3〜31 における IRT を、横軸に延床面積を取って示したものが 


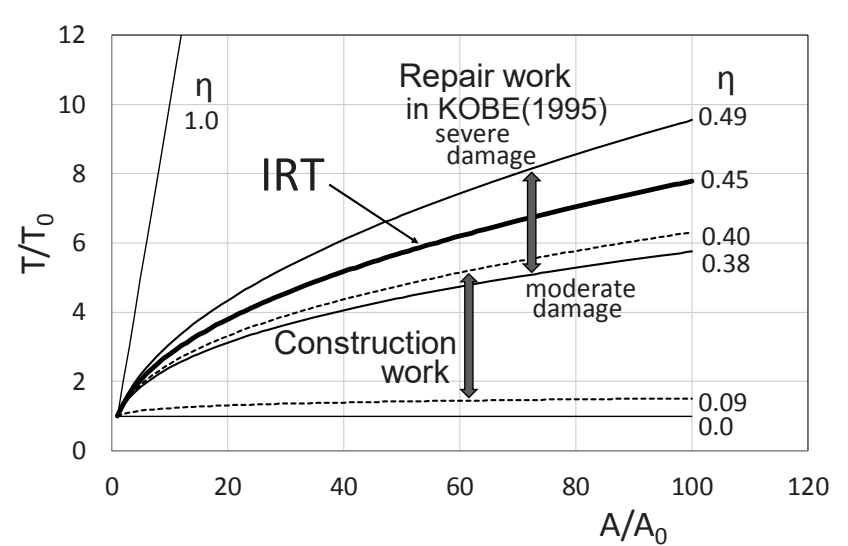

Fig.12 Relative Increase in Repair Time with Total Floor Area

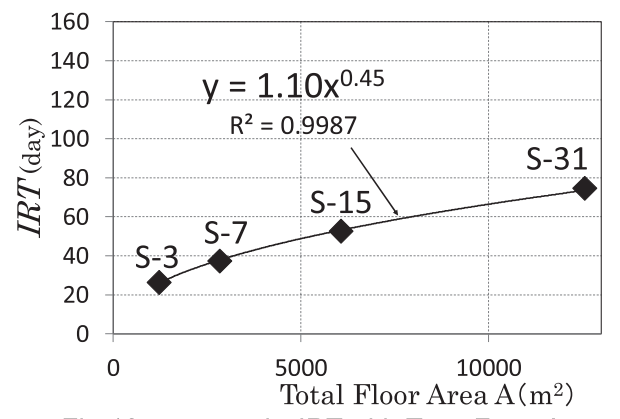

Fig.13 Increase in IRT with Total Floor Area

Fig.13 である。図中には(28)式の形を仮定した近似曲線が示されて いる。 $\eta$ の值を 0.45 とした近似曲線は十分な精度で増加傾向を捉え ていることが分かる。

$\eta$ の值を 0.45 とした(29)式から算出される工期の相対的増加を、 建設工事や実際の修復工事のものと比較し太実線で Fig.12 中に示 した。太実線は、実修復時間をもとに諏訪が導き出した中破と大破 の曲線の間に位置していることが分かる。解析対象建物において、 損傷の大きくなる $1 \cdot 2$ 層の梁の部材角は $1 / 50$ 程度である。各解析 ケースは抄よと中破から大破程度の損傷状態にあると考えられ、 これに対する $\eta$ の值として 0.45 は妥当なものと思われる。

\section{2 実修復時間との定量的な比較}

先に述べたようにIRT は要因 IV 〜 IXの影響を排除した、損傷状態 （要因 I II III）の夕から定まる修復時間である。一般に個々の現場に おける要因IV〜IXの状態は異なり、この影響で修復時間は変化する。 このため IRT はそれらの修復時間（実修復時間）とは一致しないと 考えられる。しかしながら、建物の耐損傷性評価において、予想さ れる損傷状態に対する修復時間の目安として IRT を使用すること を想定しており、IRT が実修復時間と量的にあまりにかけ離れたも のになっているのでは指標の有用性の観点から問題である。以下で はIRT と実修復時間との量的関係について考察する。

Fig.14に、諏訪によって調查された中破及び大破建物の実修復時 間 ${ }^{14)}$ と、Y 方向のスパン数を増加させ延床面積を変化させた各解析 ケース S-3〜31のIRT、さらに、それら IRT に対する近似曲線を示 した。なお、実修復時間は暦日日数であることから、この図におけ るIRTには、年間 77 日の日曜・祝日を作業不能日と仮定した補正係 数 $(=360 /(360-77))$ を乗じ暦日日数への変換を行っている。

Fig.14に示されている実修復時間のプロットは、ばらつきの大き なものとなっている。これは、同じ中破・大破建物でも、先に述心

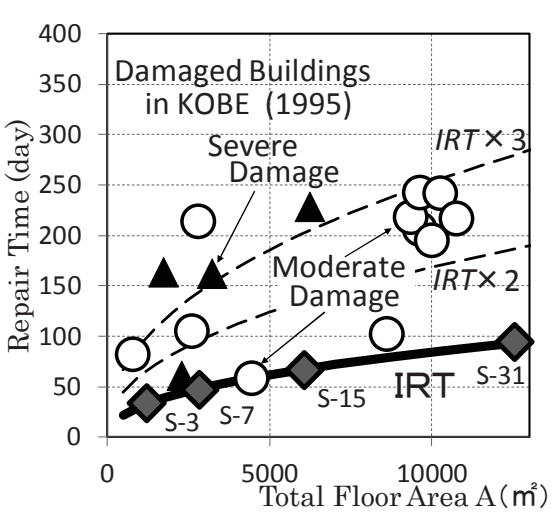

Fig.14 Repair time in KOBE Earthquake (1995) and IRT

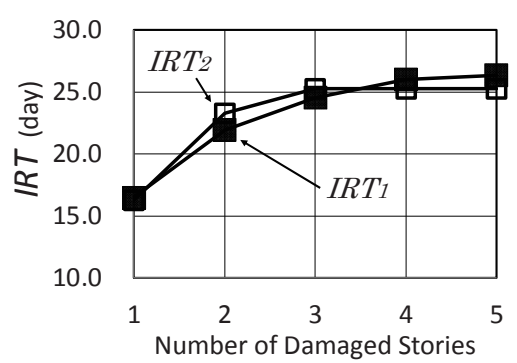

Fig.15 Effect of Amount and Extent of damage on IRT

た損傷の量・広がり・質（要因 I II III）が異なる可能性があること、 また、損傷状態以外の要因IV〜IXの影響を受け修復時間は増加ある いは減少するためと考えられる。

Fig.14 から、算出された IRT は実修復時間のプロット群のおおよ そ下限に位置していることが分かる。IRT が実修復時間と比較し小 さくなる要因として、解析対象とした建物に間仕切り壁等の非構造 部材が存在しておらずIRTが躯体のみの損傷から算出されているこ とが挙げられる。

著者らは、労務量 $L$ を元にした、修復費用の観点から損傷の深刻 度を評価する指標（修復性評価指標）の提案を行っている5)。文献 15)ではこの指標の試算が行われ、非構造部材が入ることによって提 案指標は、躯体のみの場合の 2.5 倍程度に増加寸ることが示されて いる。このことは、非構造部材の存在によって労務量 $L$ が 2.5 倍程 度増加することを意味しており、IRT 、IRT 2 の定義((23)(25)式)から 考えて、これにより IRT は $\sqrt{2.5} 2.5$ 倍程度増加寸ると考えること ができる。Fig.14 中には IRTを 2 倍・3 倍した曲線が示されている が、非構造部材の損傷を算入した場合、各解析ケースのIRT は実修 復時間のデータ群の中を通りプロットされるものと推察される。

要因 I II III から定まる IRT は実修復時間と大きくかけ離れたもの とはなっておらず、また、おおよその実修復時間の増加傾向を表現 できていると言える。このことは、要因 I II III、すなわち、損傷状 態は修復時間増加の主な要因となっていることを示唆するものと考 えられる。

\section{3 建物所有者によるIRTを用いた最適崩壊形選択の可能性}

全層に損傷が生じた解析ケース S-3 の損傷を、上層から順に取り 除いた場合のIRT の変化を見たものが Fig. 15 である。図中の横軸の 数字は、損傷を残した層の数であり、例えば「3」とは上層の 2 層の 損傷を取り除いたケースを意味する。この図から、全層崩壊では IRT が 26.4 日であるが、 $5 \sim 2$ 層の損傷を取り除いた 1 層の夕損傷のケ 
ースではIRTが 16 日程度まで減少していることが分かる。

事業継続性計画（以下、BCP）の策定に際して、目標復旧時間（以 下、RTO）の設定が各事業者に求められている。RTO は機能停止が 財務状況や取引先との関係に及ぼす影響をもとに定められる。例え ば、中小企業庁のウェブページには、 1 日から 1 ケ月までの RTO の 設定事例が示されている16)。

RTO を例えば 1 ケ月 $(31$ 日) とし、地震発生から修復工事開始まで の期間として 10 日を見込む場合、目標の修復時間は 21 日となる。 この場合、 $I R T=26.4$ 日となる全層崩壊の損傷は過多であり、耐損傷 性能は不足していると言える。一方、先に述べたように $5 \sim 2$ 層の 損傷を取り除いた 1 層のみ損傷とした場合の IRT は約 16 日である。 実際の修復時間は、考虑されていない要因IV〜IXのために、これよ りさらに大きくなる可能性もあるが、IRT は目標の 21 日と比べて小 さく、許容範囲内の損傷と判断される可能性が高くなる。なお、実 際の耐震損傷性の検討は仕上げや設備等の損傷が考慮されたIRTに 基づき行われる必要がある。

このような判断は、必ずしも耐震工学に関する知識を必要とせず、 建物の使用状況や機能的な重要性を熟知し、RTO を定めることので きる建物所有者にとってより適したものである。設計者は、建物所 有者との IRTを用いた対話を通して、修復時間に対寸る要求レベル の把握を行うとともに、損傷階を限定することによる安全性能の低 下など、建物に必要な性能を総合的に考慮して設計を進めることに なる。提案指標は BCP の普及を背景に、安全性のみの観点からの 崩壊モード選択とは異なる、建物所有者の立場からの機能継続性の 観点も加えた、より設計対象建物に適した崩壊モード選択を可能に すると言える。

\section{7. まとめ}

地震後機能回復性の観点から損傷の深刻度を相対的に評価する指 標（理想修復時間 $I R T ） の$ 提案を行った。この指標において、損傷の 深刻度とは、修復時間が相対的に大きくなることと定義した。IRT は、 耐損傷性能の確保を目標とした耐震設計法における目標性能レベル の設定や耐震性能レベルの評価に用いられることを想定している。

$I R T$ の妥当性・有用性に関する考察を以下にまとめる。

1. IRT は地震時の実際の修復時間（実修復時間）を評価すること を目的としたものではなく、損傷状態（要因 I II III : 損傷の量・広 がり・質）が引き起こす深刻度（損傷状態から決まる修復時間）を 相対的に評価する、一種の構造性能評価指標である。そのため、 Table 1 に示した損傷状態以外の要因IV〜IX、寸なわち、周辺環境や 施主の希望する工期など、建物の構造性能と関係のない要因の影響 を、算定上の仮定を設けることによって排除している。実修復時間 は、同じ損傷状態であっても、建物の構造性能と関係のない要因IV 〜IXが異なると異なってくるため、構造性能評価指標として使用す ることはできない。一方、これら要因IV〜IXの影響を排除した、損 傷状態のみから定まるIRT は、構造性能を評価する指標として有用 と考えられる。

2. 既往の研究で示されている、建物建設における工事の量と広が りがもたらす工期の増加傾向および、兵庫県南部地震における実修 復時間をもとに、損傷の量と広がりが引き起こす修復時間の相対的 増加に対してIRT が妥当な評価を与えることを示した。
3. 要因 I II IIIから定まるIRT は兵庫県南部地震における実修復時 間と大きくかけ離れたものとはならず、また、損傷の量・広がりの 増加に伴う実修復時間の増加傾向をおおよそ表現できるものとなっ た。このことは、要因 I II III（損傷状態）が修復時間増加の主要因 となっており、要因 I II IIIから定まるIRTに基づく設計が、実修復 時間の低減に対して有効であることを示唆するものである。

4. 大地震に対する機能回復性についての法的な縛りは無く基本的 に性能の過不足は特別な専門知識のない建物所有者の判断に委衫ら れる。IRT は地震時に予想される損傷修復のための時間を評価した ものであり、損傷の深刻度を建物所有者が容易に理解することがで きる。耐損傷性能を目標とした設計を行う上で、建物所有者に、耐 損傷性能の必要性と、確保されている耐震性能のレベルを示すこと のできる指標の存在は重要である。

今後の課題として次のことが挙げられる。

1.IRTでは損傷状態以外の要因の影響が無視されているため、IRT の量的評価の妥当性を、実修復時間との比較を通して論じることに は限界がある。今後、損傷状態以外の要因の影響を受けない人工的 環境における修復時間、例えば、実験棟における修復実験などから 得られる修復時間をもとに IRT の量的評価の妥当性の検討を行う 必要がある。

2. 今回の IRTの試算では、解析対象フレームの柱部材・梁部材の 損傷度評価（時間損傷度 $t d i$ の評価）に、シアスパン比・軸力比・ 破壊モードなどの構造的特徵が類似する部材の損傷実験データを用 いた。しかしながら、多様な建物のIRT評価を行うためには、構造 的特徵の異なる種々の部材の時間損傷度 $t d i$ を部材角等から推定す るモデルの構築が必要となる。この目的のために、最近の実験的研 究によって蓄積されてきている部材損傷情報デー夕例えば $2,3,4,7)$ を 活用寸ることが考えられる。

\section{参考文献}

1) Architectural Institute of Japan: Preliminary Reconnaissance Report of the 2011 Tohoku-Chiho Taiheiyo-Oki Earthquake, Maruzen Publishing Co., Ltd., 2011. 7 (in Japanese)

日本建築学会: 2011 年東北地方太平洋沖地震災害調査速報, 丸善出版株式 会社, 2011. 7

2) Aoki, T. and Maeda, M.: Proposal and Application of Damage Index for Evaluation of Reparability for RC Buildings, Proceedings of the JCI, Vol.33, No.2, pp. 913-918, 2011. 7 (in Japanese) 青木貴, 前田匡樹： $\mathrm{RC}$ 造建物の耐震修復性及び修復限界状態の評価を目 的とした損傷量指標の提案と建物モデルへの適用例, コンクリート工学年 次論文集, Vol.33, No.2, pp. 913-918, 2011.7

3) Takahashi, N., Takahashi, E. and Nakano, Y.: Demonstration of the Evaluation Method for Quantity of Cracks in RC members, Proceedings of the JCI, Vol.31, No.2, pp. 859-864, 2009. 7 (in Japanese) 高橋典之, 高橋絵里, 中埜良昭：鉄筋コンクリート部材のひび割れ量推定 モデルの検証，コンクリート工学年次論文集，Vol.31, No.2, pp. 859-864, 2009. 7

4) Mukai, T., Fukuyama, H. and 3 other: Proceedings of Development on New Structural Performance Evaluation System for Disaster Resilience Buildings, Building Research Institute, 2011. 1 (in Japanese) 向井智久, 福山洋 ほか 3 名：災害後の建築物の機能維持・早期回復を目 指した構造性能評価システムの開発 成果報告書, 建築研究所 BRI Proceedings No.20, 2011. 1

5) Kinugasa, H., Mukai, T. and 4 other: Proposal of Index for Reparability Evaluation of Buildings based on Engineering Factors in Repair Cost 
Increase, AIJ Journal of Technology and Design, Vol.17, No.36, pp. 531536, 2011. 6 (in Japanese)

衣笠秀行, 向井智久, ほか 4 名：修復費用の工学的増加要因に基づく修復 性評価指標の提案, 日本建築学会技術報告集, Vol.17, No.36, pp. 531-536, 2011. 6

6) Kikitsu, H., Mukai, T. and 6 other: Structural Design and Seismic Performance Evaluation for New Buildings with Post-EQ FunctionalUse, Part 1 Outline of Performance Required for Post-EQ FunctionalUse, Summaries of Technical Papers of Annual Meeting, Architectural Institute of Japan, Structure-1, pp. 45-46, 2015. 9 (in Japanese) 喜々津仁密, 向井智久, ほか 6 名：地震後の継続使用性を確保した新築 建築物の設計 ・耐震性能評価, その 1 継続使用性に関寸る要求性能, 日 本建築学会大会学術講演梗概集, 構造 I, pp. 45-46, 2015.9

7) Architectural Institute of Japan: Guidelines for Performance Evaluation of Earthquake Resistant Reinforced Concrete Buildings (Draft), 2004. 1 (in Japanese)

日本建築学会：鉄筋コンクリート造建物の耐震性能評価指針 (案) ・同解 説, 2004. 1

8) The Japan Building Disaster Prevention Association: Guideline for Post-earthquake Damage Evaluation and Rehabilitation, 2001. 9 (in Japanese)

日本建築防災協会：震災建築物の被災度区分判定基準および復旧技術指 針, 2002. 8

9) Research Society for Process Planning: Practical Work of Preparing Construction Process Chart, Shokokusha Publishing Co.,Ltd., 2003. 12 (in Japanese)

工程計画研究会：建築工程表の作成実務 第二版, 彰国社, 2003. 12

10) Research Institute on Building Cost: Estimation Manual for Repair Work of Public Building, Taisei Publishing Co., Ltd.,2006. 2 (in Japanese)

国土交通省大臣官房官庁営繥部・建築コスト管理システム研究所：公共 建築改修工事の積算マニュアル，大成出版社, 2006. 2

11) Sasama, K.: Research on Standard Construction Period (1), Introduction and Relation between Floor Area and Number of Workers, A.I.J. Research report (51), pp. 23-26, 1960. 3 (in Japanese) 笹間一夫：標準工期に関する研究 (1), 序論及び建築の面積と出面との 関係, 日本建築学会研究報告 (51), pp. 23-26, 1960.3

12) Fukuyama, H., Mukai, T. and 8 other: Experimental Test on Structural Performance for RC Frame with Brittle Column, Part.1-8, Summaries of Technical Papers of Annual Meeting, Architectural Institute of Japan, Structure-4, pp. 807-822, 2011. 8 (in Japanese)

福山洋, 向井智久, ほか 8 名: 脆性部材を有する $\mathrm{RC}$ 造架構の構造性能評 価に関する実験 (その 1)～(その 8), 日本建築学会大会学術講演梗概集, 構造IV, pp. 807-822, 2011.8

13) Katou, T., Handa, M. and 3 other: Formularizing an Equation for Calculating the Approximate Construction Period, Study on method for calculating construction period (Part 3), Journal of Architecture and Planning (Transactions of AIJ), No.584, pp. 115-120, 2004. 10 (in Japanese)

加藤辰彦，半田雅俊，ほか 3 名：単位工期概算式の定式化，建設工期の算 定方法に関する研究（その 3）, 日本建築学会計画系論文集, 第 584 号, pp. 115-120, 2004. 10

14) Suwa, H. and Kanda, J.: Statistical Consideration on Building Repair Time due to 1995 Hyogoken Nanbu Earthquake, Journal of Structural Engineering, Vol.53B, pp. 311-316, 2007. 3 (in Japanese)

諏訪仁，神田順：兵庫県南部地震の被害データを用いた建物補修期間の統 計的検討, 構造工学論文集, Vol.53B, pp. 311-316, 2007. 3

15) Kinugasa, H., Izumi, K. and 2 other: Reparability Evaluation for RC Structure using Reparability Evaluation Index, Total Repair Time and Repair Cost Coefficient, Proceedings of the JCI, Vol.35, No.2, pp. 877882, 2013. 7 (in Japanese)

衣笠秀行, 泉洪介 ほか 2 名：修復性評価指標・総修復時間・修復費用係数 を用いた RC 造建物の修復難易度評価, コンクリート工学年次論文集,
Vol.35, No.2, pp. 877-882, 2013. 7

16) The Small and Medium Enterprise Agency: Example of Recovery Time Objective (in Japanese),

http://www.chusho.meti.go.jp/bcp/contents/level_b/bcpgl_08_05.html, accessed 2018. 8. 1

中小企業庁：目標復旧時間に関する参考事例, http://www.chusho.meti.go.jp/bcp/contents/level_b/bcpgl_08_05.html, 2018. 8. 1 参照 


\section{DAMAGE EVALUATION INDEX FROM THE VIEWPOINT OF POST-SEISMIC FUNCTIONAL RECOVERY}

\section{Hideyuki KINUGASA ${ }^{* 1}$ and Tomohisa MUKAI*2}

\footnotetext{
${ }^{* 1}$ Prof., Dept. of Architecture, Faculty of Science and Engineering, Tokyo Univ. of Science, Ph.D.

${ }^{* 2}$ Senior Research Engineer, Dept. of Structural Engineering, Building Research Institute, Dr.Eng.
}

In particular, when designing a high-rise building, it is recommended that the entire collapse mechanism (i.e. strong column-weak beam mechanism) be planned and sufficient safety of the building be ensured by allowing earthquake damage to spread throughout the building and by ensuring that the energy generated by the earthquake is absorbed evenly by the entire building. However, it is a matter of serious concern that the damage on every floor causes extensive spreading of the area to be restored, greatly increases the repair cost, and lengthens the restoration period, making functional recovery difficult.

Developing design methods that consider the safety and post-seismic functionality of buildings is required to reduce damage to buildings and minimize damage to society from major earthquakes. A damage evaluation index which can properly evaluate the severity of the damage from the viewpoint of post-seismic functional recovery is necessary for such design. The authors in this study define the severity of the damage as that which repair time is becoming relatively large. And an "ideal repair time (IRT)", which is an index that relatively evaluates the severity of the damage, is proposed.

The IRT has the following features:

1. Many factors influence the repair time other than the damage state. These factors include the social and surrounding environments, climate, adopted repair methods, work procedures, number of engaged workers, and work proficiency, among others. The repair time would still vary when these factors are different even if the damage state is the same. The IRT is a damage evaluation index that targets only the damage state (i.e., amount, extent, and quality of the damage) by eliminating influences of factors other than the damage state.

2. From the comparison between the $I R T$ and repair time of damaged buildings in KOBE Earthquake, it was shown that the IRT reasonably evaluates the relative increase in repair time generated by amount and extent of the damage. Furthermore, the validity of quantitative evaluation by IRT was discussed, considering the calculation condition and its influence on repair time.

3. The IRT evaluates the severity of the damage caused by its amount and extent. Therefore, the influence on the dysfunctional time by each damage in the building can be evaluated, and the damaged areas to be prevented can be identified. The analysis based on the $I R T$ allows structural designers to investigate the validity of the planned collapse mechanism, strength, and stiffness given to the building from the perspective of the post-seismic functional recovery.

4. The IRT is an index that represents the dysfunctional time caused by the damage. From the IRT, ordinary people with no special knowledge on structural engineering can easily understand the relative difference of the damage severity and the damage-resistant performance given to the building. An index that can indicate the necessity of the damageresistant performance and the secured level of the performance to the owner of the building is significant. 